\title{
Service Report from Pennsylvania
}

Mr. Hamlin, formerly assistant librarian, Service Division, University of Pennsylvania Library, is the new executive secretary of A.C.R.L.

$\mathrm{D}$ URING THE course of four years' operation of the Service Division at the University of Pennsylvania, the writer has experimented with a number of techniques and policies which are not standard doctrine for large, urban university libraries. While very few of the operating procedures discussed below are original at Pennsylvania, they are deviations from textbook doctrine. This report is made in the belief that this experience will be useful, in one way or another, to some other large university libraries.

The University of Pennsylvania now has a peak enrollment of 19,000 , of which about I0,000 are full-time students. It is situated close to the center of Philadelphia. The library building was erected in $\mathrm{I} 89 \mathrm{I}$ and has all the limitations of the design of that era. It was originally planned for a book stock and a student body one-tenth the present size. There have been additions, but the last of consequence was built in I 924.

\section{Open Stack}

The library has traditionally given stack access only to faculty and graduate students. The usual arguments of narrow aisles, crowded shelves (operation is on a basis of about 22 volumes per square foot at present), and inadequate desk and carrel equipment reinforced this ruling. In spite of all this, the stack was opened to juniors and seniors two years ago on a trial basis. The extension of this privilege has worked out far better than anyone dared hope. There have been no known abuses, no overcrowding, no disorder. With the increased use of stack facilities, there have been more books to put away and more litter to sweep up, but the slight increase in operating cost is minor in light of the considerable advantages to the students who use this privilege.

There are several conclusions to be drawn from our experience:

(a) Few students are vitally interested in the privilege. To others, the stack is not sufficiently important, open or closed, to compete with football games, dates, and many other extracurricular activities.

(b) Undergraduates are as careful, and probably more careful, about putting books back in place (or leaving them in the proper places for stack assistants to shelve) than graduate students and faculty, who assume certain prerogatives and often become careless.

(c) Fears of disciplinary problems with both sexes using a large and dimly-lighted stack are false fears. Less than two dozen book mutilations were reported (all discovcovered are reported) for the main library during the past year. Many of these are kriown to have taken place outside the stack. The loss of books is small, principally because all books are inspected at the exit of the building.

(d) Stack permission is a tremendous boon to a few conscientious, eager undergraduates. It is used occasionally and appreciated by possibly one-third (certainly less than one-half) of those who might use it. The majority confine their library use to subject, reserve, or other reading rooms, 
and use the circulation desk pages for books occasionally required from the stack. Interest in the bookstack is assumed to be much greater at institutions where most students live on campus and where plant facilities are modern.

(e) It is the personal conviction of the writer that while undergraduates may "knock about" in the stack at first, and have difficulties of all sorts, this time is hardly wasted. There are few who do not eventually find, possibly with help, the desired section; there are fewer who can leave a great bookstack without bumping into some titles which arouse their interest. Some read the wrong things, but at least they are reading. Only when more undergraduates here and elsewhere are reading regularly above and beyond the requirements for tomorrow's quiz, should librarians worry about the quality and direction of the reading.

Last May, the Faculty Library Committee declared unanimously in favor of an open stack for all undergraduates. Freshmen and sophomores will be required to attend a short talk on the bookstack before receiving their permits. There is little fear anywhere that this extension will materially increase operating costs or interfere with the work of mature scholars. It will be interesting to compare the use of this old bookstack with use of the modern facilities in the new building which may possibly be completed at Pennsylvania within the next three years.

\section{Carrels}

The present stack study facilities at the University of Pennsylvania Library consist of 54 open cubicles and about as many small desks. Even with double assignment, these do not meet the demand. For the past two years, no cubicles have been assigned to anyone. Instead, individual shelves are provided adjacent to carrels and desks.
Books are charged to these shelves, and the user occupies any vacant place when he comes in to work. It is our experience that very few people use cubicles for the larger part of every working day. Use of carrels should go to those who come in the library to work, regardless of academic rank. This policy has been sufficiently successful in practice to be incorporated in plans for the new building. The original number of carrels planned has been cut in half. In place of shelves, provision is made for lockers with glass doors, large enough for portable typewriters and a dozen books or more. The Angus Snead MacDonald Corporation has blueprinted a carrel-cabinet installation based on this principle.

\section{Smoking}

In large university libraries, smoking is often banned or limited to an unpleasant smoking room on the basis of fire hazard. In most library buildings there are at least some reading rooms where the fire hazard is practically nonexistent, and where insurance rates are not effected as long as ash trays and sand containers are provided.

A cleaning problem is obviously involved. The smoking room at Pennsylvania is equipped principally with benches and a very few smok-a-dors. Almost all ash and remainder go on the floor rather than into the containers. On the other hand, when smoking was permitted in a small reading room, there was no cleaning problem whatsoever. Here the only place to sit is at tables. On these tables are scattered at least half as many ash trays as there are chairs in the room. People who do not like smoke use an adjacent room. Contrary to expectation, the tables are not burned. There is no evidence of any damage to books. For better or worse, smoking is a part of the present-day way of life and should be permitted in some convenient working areas of any library. 


\section{Microfilm Storage}

Microfilms are no longer kept in steel microfilm cabinets, but on shelves in a small, controlled room off the circulation desk. One single-faced section of wooden stack takes about 266 boxes without "double-shelving." Aisles can be two feet or slightly less. This is space economy.

As far as humidity is concerned, the eastern seaboard has more than enough in summer. During the winter months, ventilating equipment in the stack draws air through a water spray which brings the water content up to what seems to be a safe factor. Open pans of water will provide sufficient humidity to combat the drying effect of winter heat in small, closed rooms anywhere.

A certain amount of dust does collect on the boxes but no appreciable amount penetrates. We believe the preservation of film depends more on the care with which it is used than on these storage factors. To this end, readers who use microfilm for the first time are pretty thoroughly indoctrinated and the staff keeps a close eye on the special room when the microfilm readers are used.

\section{Reserve Book Policies}

While the traditional large reserve reading room is a feature enforced upon us by building limitations, several departures from traditional operation may be of interest to other libraries.

Ninety per cent of the books are openshelved. Four fifths of the books are allowed to circulate for 24 hours or more.

Each of the five staff members is responsible for one or several departments of instruction. The assistant prompts her professors or departmental secretaries to send in lists and outlines of assignments. Within her assigned fields, she regularly increases or decreases the period of loan or restriction of individual volumes on the basis of use, or on the basis of assignments past or future. She may, and often does, return a book to stack even though still included on assignment sheets if it has, in practice, had little or no use.

This division of authority under the head of the department allows for a degree of personal attention and supervision otherwise not possible. None of the staff members are trained librarians; they are all recent college graduates. We find them capable of making intelligent decisions and using initiative after a relatively short indoctrination.

\section{Interlibrary Loans}

The attitude of this library toward interlibrary loans has been recently stated in detail. ${ }^{1}$ Suffice it to say, the operations called for in the national code require a detail of bookkeeping, acknowledgment and general clerical routine that make the cost dangerously high.

In August 1949, interlibrary loans were taken away from the Reference Department and made the responsibility of one person without professional training but with an excellent background in library techniques. The Reference Department is called on occasionally for bibliographical help.

Books loaned by this library are loaned directly by circulation. While replies are made to all applications for loan, the other acknowledgments of receipt, etc. are largely given up. No records of postage are kept here, although reimbursement is expected. Shipping labels are expected from the borrowing library and return labels are furnished with the books. A concise mimeographed statement is enclosed with each package, explaining Pennsylvania practice and what is expected of the borrowing library.

The library is now feeling its way to1 Charles W. David, "Remarks, on Interlibrary
Loan, Mid-twentieth Century Style," College and Re. search Libraries 10:429-33, October 1949. 
ward similar simplification of procedures when it borrows. It expects cooperation from those institutions which borrow more than they lend, but Pennsylvania will, of course, follow the Interlibrary Loan Code procedure in detail when requested.

Interlibrary loans were once relatively rare occurrences, but are now known and used by practically all advanced students in this country. The hand-tailored operation of an earlier day with its formal courtesies is so costly that it threatens to limit this wise practice of exchanging books. The bibliographical work requiring a trained person is a relatively small part of the loaning procedure. The majority of the labor is clerical and can safely be intrusted to a diligent nonprofessional. Quite naturally, exception must be made for books of more than average value. Supervision must be exercised regarding what to loan and what to borrow. The cost of the normal loan should not be much higher than the cost of mailing out a volume to any regular borrower who has sprained an ankle and can't come in for his material.

\section{Insurance}

The University of Pennsylvania carries "all risk" insurance on its book stock for a very large sum. The difference between "fire only" and "all risk," which includes theft or loss, is very small indeed. Annual losses from the reserve book reading room, while relatively small, more than recompense the library for this premium. Naturally, such a pleasant state of affairs cannot continue indefinitely.

The policy is worded so as to cover books borrowed from other libraries from the time the books leave the loaning building. Books which we loan elsewhere are the responsibility of the borrower. In sending, Pennsylvania therefore insures these at full value.

Advantage can often be taken of the lower express "book rate" by placing the valuation at $\$ 10.00$ even though the actual value (covered by the policy) is much higher. This low valuation has sometimes caused misunderstanding with other libraries.

The thick volume of Rate Scales Applying from Philadelphia of the Railway Express Agency ( 1947) makes no mention of "book rate," which is about three-eighths cheaper than the regular rate. The local Express Agency has not always been diligent in applying the lower rate. A long series of refund claims have been cheerfully accepted and mistakes no longer occur.

\section{Staff}

Out of a staff of 33 full-time Service Division employees in the Main Library, only six have professional library training or the equivalent. Four of these comprise the reference staff and the other two head the Circulation and Reserve Book Departments respectively.

Judging from the published statistics of other libraries, this- is a very low ratio of professional to nonprofessional. It could not possibly be carried lower, and the addition of one or two professionals is desirable. Any increase beyond that is certainly considered unnecessary.

As we operate, the policies and techniques at reserve and circulation are carefully formulated and written up in detail. We depend on a corps of intelligent young women a few years out of college for execution of all except secretarial and stack work. It has been our experience that inexperienced young people can be taught the reserve and circulation routines in a relatively short time, that they are helpful and cooperative in public positions, and that a fair measure of discretion can be allowed them in the execution of what are principally routine duties. Many of these young women have a great deal of judgment, tact and discre- 
tion in applying rules and policies. They have a sympathy for readers which is not always found in professionals. Matters requiring professional knowledge are always sent to the reference desk.

\section{Discipline}

The attitude of the library toward its public (and vice versa), entailing as it does disciplinary policies, has been a matter of concern to the library administration. A turnstile type of exit control was installed in I946, and it took time for students and faculty to accept this. At the same time, the library junked hundreds of running feet of counters which, in one way or another, stood between readers and books.

This library has relatively low fines. It accepts as truthful (and therefore forgives) all sorts of excuses for late return or nonreturn on books. However, temporary, informal records of "pardons" are kept at the public desks, and any person who oversteps the bounds of human credulity gets rough treatment. The library withdraws the privilege of using the building for short periods, recommends disciplinary action, and "prosecutes" before the proper officials when serious delinquency is involved. About onethird of the mutilations reported in the past two years have either been tracked to the guilty party (in most cases, expelled) or narrowed down sufficiently close to give the probably guilty but unconfessing student a real scare.

In the course of a year or more of possibly using too heavy a hand on a few culprits, the word has gone around campus that the library means business. It therefore gets good cooperation. As a consequence, fines have been abandoned at one public desk and restrictions in certain other directions have been eased or wiped out.

\section{Borrowing Privileges for Outsiders}

The policy of the University of Pennsyl- vania Library in granting borrowing privileges to people not connected with the university is not at the moment a matter for public record. Over a period of several years, the writer has had full discretion in granting permission (free) to outsiders and has built up experience and conviction regarding the extension of borrowing privileges.

In spite of the fact that the library is near the center of a great metropolitan area, no great numbers of people are particularly interested in using its books. The experience of public libraries, designed and stocked for the average man and promoted by all the modern methods of publicity, is sufficient evidence of public apathy. Only a very small minority of the population need and want borrowing privileges at university libraries. These people are, with few exceptions, mature and serious students and scholars.

The University of Pennsylvania Committee on Educational Policy and Planning reported the aims of the University several years ago as follows:

Generally speaking there are three ways in which Pennsylvania, like other institutions of higher learning, performs its educational function and makes its contribution to social progress. One is by providing as many students as it can serve well with the education which will make them useful members of society, thereby fulfilling its function of leadership and contributing its share of leaders to the community and to the country. A second is by training qualified men and women for various professions which require specialized knowledge or high technical skill. And a third is by extending the bounds of knowledge through research and training of others for research by which mankind approaches closer to the truth or gains greater control over its environment.

According to this statement, the library has definite responsibilities outside the university family. Now it is customary with American libraries to allow any serious, 
sober citizen the use of books within the building. Is it not far more practical to allow the outsider to take his book with him and use it at home, provided the volume is not restricted because of class use, reference use, fragility, rarity, etc. ?

Home use is a great convenience to most people. The trust implicit in such a loan will occasionally return dividends. (Many have joined the "Friends" because of the borrowing privilege. Checks as high as \$50 have come from these people.) There need be no special fear of the book thief, who will steal regardless of the borrowing privilege. Pennsylvania has had almost no trouble with late return, and promptly weeds out the careless. On many occasions, loans of single books have been approved for-people who were transients, without request for any identification. An honest-looking, decently dressed stranger with a good reason for reading a book and enough urgency to come to the university library is a pretty safe bet for a loan worth at most a few dollars. Loaning a book for home use is about the cheapest thing a library can do. Reference service, reading room privilege, and so on are all far more expensive. The general restriction of this privilege at the large university libraries is, in the light of our fairly long, extensive experience at Pennsylvania, based on fears which seem completely unwarranted. There is an opportunity here for the university to do a great public service and win considerable good will at very small expense, provided good judgment is exercised. The then President Gates stated the goal concisely some years ago:

The University of Pennsylvania Library . . . accepts ... a responsibility for service to the community at large and to the student world at large. It opens its doors and extends its facilities liberally to all those seeking knowledge out of books ... .'

2 Bibliographical Planning Committee of Philadelphia, Philadelphia Libraries, a Survey of Facilities, Needs, and Opportunities. University of Pennsylvania Press, $194^{2}$, p. 59.

\title{
Historical Libraries - New Style
}

\author{
(Continued from page 62)
}

torical library have been confused and interdependent. Scholars have traveled to far countries at great expense in order to read books and manuscripts not available at home. Today the texts, as texts, are being made available almost anywhere. But in their quality as museum pieces the books themselves are not transportable by such means. Their prestige value and their text value are now clearly separable, with marked benefits to the peace of mind of the historical librarian. He administers, for research purposes, not merely the actual books in his own library, not merely such microfilm copies as he may have secured from other collections, but potentially all the pertinent texts in the public libraries of. the world. He administers, for museum purposes, as many fine books, illustrated manuscripts, artistic bindings and other rarities as he is able to assemble in his own institution, where persons of education and discernment may admire and enjoy them. In a society such as ours it would be venturesome to say that either of these purposes is more important than the other. 